Martyna Karolina BojKO

SWPS University, Warsaw, Poland

DOI: $10.13166 / \mathrm{JMS} / 138316$

JOURNAL OF MODERN

bojkomartyna@gmail.com

SCIENCE TOM 1/46/2021,

S. 355-375

\title{
THE WAY TO ENFORCEMENT UNDER A MEDIATION AGREEMENT
}

\author{
DROGA DO EGZEKUCJI NA PODSTAWIE \\ UGODY MEDIACYJNEJ
}

\begin{abstract}
The main research objective of this article is to analyze whether it is true that in the event of failure to comply with the provisions of a settlement under which the parties undertook to provide a specific benefit, an effective solution is apply for an enforcement clause for a mediation settlement, obtain an enforcement order, and referring the case to enforcement proceedings. The article describes the issues related to the mediation settlement and the necessary formal and substantive conditions for the settlement for the subsequent enforcement procedure. The article uses mainly the dogmatic and a legal method. The article presents both theoretical scientific issues and practical related issues with a mediation settlement, the provisions of such settlement, and the manner of pursuing a claim based on a mediation agreement. Therefore, the conditions for approving the mediation settlement or giving it an enforcement clause by the court, the conditions for recognizing the settlement as an enforceable title, and then an enforcement order were analyzed. Refusal to approve the settlement or issuing an enforcement clause and the possibility of a subsequent appeal against the provisions in this regard. The conclusion of the article is primarily that in the event of failure to comply with the settlement, only the appropriate form of the provisions contained, therein and the fulfillment of certain conditions allows it to be issued an enforcement clause, and then to conduct enforcement proceedings.
\end{abstract}




\section{STRESZCZENIE}

Głównym celem badawczym przedmiotowego artykułu jest analiza tego, czy prawdziwe jest twierdzenie, że w przypadku niewywiązania się z postanowień ugody, w ramach której strony zobowiązały się do zrealizowania określonego świadczenia, skutecznym rozwiązaniem jest złożenie wniosku o nadanie klauzuli wykonalności ugodzie mediacyjnej, uzyskanie tytułu wykonawczegoi skierowanie sprawy na droge postępowania egzekucyjnego. Artykuł opisuje problematykę dotyczącą ugody mediacyjnej oraz niezbędne warunki formalne oraz merytoryczne ugody w kontekście późniejszej drogi egzekucyjnej. W artykule posłużono się głównie metodą dogmatyczno-prawną. Zaprezentowano zarówno teoretyczne zagadnienia naukowe, jak i praktyczne kwestie związane z ugodą mediacyjną, postanowieniami takiej ugody oraz sposobem dochodzenia roszczenia na podstawie ugody mediacyjnej. Wobec tego przeanalizowano warunki pozwalające na zatwierdzenie ugody mediacyjnej lub nadanie jej klauzuli wykonalności przez sąd, przesłanki uznania ugody za tytuł egzekucyjny, a następnie wykonawczy. Omówiono odmowę zatwierdzenia ugody lub nadania jej klauzuli wykonalności oraz możliwość późniejszego zażalenia na postanowienia w tym zakresie. $Z$ artykułu płynie przede wszystkim wniosek, że w przypadku niewywiązania się z ugody wyłącznie właściwa forma postanowień w niej ujętych oraz ziszczenie się określonych przesłanek umożliwiają nadanie jej klauzuli wykonalności, a następnie przeprowadzenie postępowania egzekucyjnego.

KEYWORDS: enforcement clause, mediation, enforcement title, settlement, settlement approval, complaint.

SŁOWA KLUCzowE: klauzula wykonalności, mediacja, tytuł egzekucyjny, tytuł wykonawczy, ugoda, zatwierdzenie ugody, zażalenie.

\section{WPROWADZENIE}

Ugoda mediacyjna ma na celu przede wszystkim zakończenie sporu pomiędzy stronami. Jest dobrowolną oraz poufną alternatywą sądowego rozwiązania sporu, która co do zasady jest szybsza, a także tańsza i wyraża wyłącznie zgodną wolę stron. Zawierana jest w trybie postępowania mediacyjnego zgodnie z postanowieniami umowy mediacyjnej, w zakresie której strony określają przedmiot mediacji oraz szczegóły dotyczące stron, a także osoby mediatora, będącej osobą trzecią, która doprowadzi do zawarcia pomiędzy nimi ugody. Przeprowadzona mediacja udokumentowana jest proto- 
kołem, który powinien określać miejsce oraz czas mediacji, imiona i nazwiska (nazwy) stron oraz mediatora, wynik mediacji, a przede wszystkim treść ewentualnie zawartej ugody (Twardowska, 2020).

Warto zaznaczyć, że w polskim porządku prawnym mediacja niezmiennie jest procedurą stosunkowo rzadko stosowaną, a najczęstszy sposób jej wszczęcia stanowi skierowanie stron do mediacji (Gmurzyńska, 2007, s. 360). Egzekucja przeprowadzana na podstawie ugody mediacyjnej jest tematem rzadko omawianym i dlatego interesującym z uwagi na liczne niejasności i złożoność tematu. Ma to niezmiennie związek z niewielkim zainteresowaniem mediacjami przez skonfliktowane strony, które pozostają w przekonaniu, że tylko proces sądowy skutecznie zakończy ich problemy. Chociaż tematyka mediacji została szeroko omówiona w literaturze przedmiotu, to jeśli chodzi o egzekucję z ugody mediacyjnej, pozostaje jeszcze duża przestrzeń na dalszą analizę oraz badania. Powyższe kwestie sprawiają, że tematyka ta jest ciekawa i wymaga przeanalizowania mediacji w kontekście egzekucji, a przede wszystkim drogi prowadzącej do wszczęcia postępowania egzekucyjnego na podstawie ugody mediacyjnej. W artykule użyta zostanie przede wszystkim metoda dogmatyczno-prawna. Jego celem jest zaprezentowanie instytucji mediacji w innym świetle niż dotychczas i wykazanie, że mediacja może stanowić skuteczny sposób rozwiązywania sporu, oraz przedstawienie, jak skutecznie dochodzić swoich roszczeń w przypadku niewywiązania się z postanowień ugody (Strumiłło, 2010, s. 111).

Za główną hipotezę badawczą przyjęto zbadanie, czy prawdziwe jest twierdzenie, że w przypadku niewywiązania się z postanowień ugody, w ramach której strony zobowiązały się do zrealizowania określonego świadczenia, skutecznym rozwiązaniem jest złożenie wniosku o nadanie klauzuli wykonalności ugodzie mediacyjnej, uzyskanie tytułu wykonawczego i skierowanie sprawy na drogę postępowania egzekucyjnego.

\section{UWAGI OGÓLNE DOTYCZĄCE MEDIACJI}

Warto zauważyć, że mediacja pozwala na dużą dowolność oraz swobodę w kształtowaniu przebiegu postępowania, które przysługują stronom biorącym w nim udział. Dopuszczalne jest przeprowadzenie mediacji zarówno 
przed wszczęciem postępowania sądowego, jak i w jego trakcie. Jednak niezależnie od wszczęcia postępowania mediacyjnego, czy to przedsądowego, czy w ramach skierowania do mediacji przez sąd, często do mediacji nie dochodzi. Zgodnie z $183^{8} \$ 2$ Kodeksu postępowania cywilnego (dalej: k.p.c.) mediacji nie prowadzi się, jeżeli strona w terminie tygodnia od dnia ogłoszenia lub doręczenia jej postanowienia kierującego strony do mediacji nie wyraziła na nią zgody (Flaga-Gieruszyńska, Zieliński, 2020).

Co istotne, mediację można zastosować w każdej sprawie, w odniesieniu do której dopuszczalne jest zawarcie ugody sądowej. Zdecydowanym celem mediacji jest doprowadzenie do rozwiązania sporu, które będzie satysfakcjonowało obie strony bez określenia, która $\mathrm{z}$ nich miała rację. Warto pamiętać, że mediacja nie powinna prowadzić tylko do zawarcia ugody oraz jej zatwierdzenia, lecz zmierzać do wsparcia stron w zażeganiu konfliktu na przyszłość (Twardowska, 2020).

Zależnie od tego, czy mediacja została przeprowadzona na podstawie umowy o mediację, czy postanowienia sądu, który skierował strony na drogę mediacji, w różny sposób mogą być budowane obowiązki mediatora, a także uprawnionych stron, w szczególności w ramach możliwości ewentualnego zatwierdzenia zawartej przed mediatorem ugody przez sąd. Warto podkreślić, że skutki prawne ugody zawartej przed mediatorem są tożsame ze skutkami ugody zawartej przed sądem (Samoiłło-Dąbrowska, 2019, s. 81). Jeśli ugoda zostanie zawarta przy udziale mediatora, wówczas mediator składa dokument protokołu w sądzie, który jest właściwy do rozpoznania sprawy zgodnie z właściwością ogólną, lub składa go do sądu kierującego sprawę do mediacji. Jeżeli zawarto ugodę, to sąd, do którego został złożony protokół, na wniosek strony prowadzi postępowanie, które zmierza do zatwierdzenia jego treści (art. $183^{13}$ k.p.c.).

Ważne dla stron postępowania jest to, że ugoda taka, jeśli zobowiązuje strony do zrealizowania konkretnego świadczenia, które podlega wykonaniu w drodze egzekucji, $\mathrm{z}$ momentem zatwierdzenia jej przez sąd poprzez nadanie klauzuli wykonalności, zgodnie $z$ art. $183^{15} \$ 1$ zdanie drugie k.p.c., staje się tytułem wykonawczym. Powyższe ma miejsce, w sytuacji gdy dłużnik nie zastosuje się do postanowień ugody, a wierzyciel wystąpi do sądu o nadanie jej klauzuli wykonalności. Wówczas ugoda zaopatrzona w klau- 
zulę wykonalności będzie tytułem wykonawczym i stanie się podstawą do złożenia wniosku o wszczęcie egzekucji przez komornika (Lichoń, 2021; Mucha, 2020, s. 49).

\section{WARUNKI POZWALAJĄCE NA ZATWIERDZENIE UGODY MEDIACYJNEJ LUB NADANIE JEJ KLAUZULI WYKONALNOŚCI PRZEZ SĄD}

Zgodnie $\mathrm{z}$ art. $183^{14} \$ 1$ k.p.c. jeżeli zawarto ugodę przed mediatorem, wówczas sąd, o którym mowa $\mathrm{w}$ art. $183{ }^{13}$ k.p.c., na wniosek strony niezwłocznie przeprowadza postępowanie co do zatwierdzenia ugody zawartej przed mediatorem. Proces zatwierdzenia ugody mediacyjnej, m.in. poprzez nadanie jej klauzuli wykonalności, poprzedzany jest badaniem przeprowadzonym przez właściwy sąd, mającym na celu stwierdzenie, czy występuje sprzeczność ugody z prawem lub zasadami współżycia społecznego, a także czy badana ugoda nie zmierza do obejścia prawa, o czym mówi art. $183^{14}$ k.p.c. $\$ 3$ k.p.c. (Góra-Błaszczykowska, Legalis 2020). Jednocześnie sąd zobowiązany jest także zbadać, czy ugoda jest zrozumiała oraz czy nie zawiera sprzeczności (I AGz 87/18, Legalis). Analizowana jest cała treść ugody.

Sąd jest uprawniony do zatwierdzenia ugody zarówno w całości, jak i w części. Częściowe jej zatwierdzenie może wystąpić w sytuacji, gdy wyłącznie część postanowień ugody odpowiada prawu lub zasadom współżycia społecznego albo będzie ona wypełniała pozostałe przesłanki, które zostały określone przepisami (https://lexplay.pl/artykul/Postepowanie-sadowe/sadowa kontrola ugody zawartej w postepowaniu mediacyjnym1).

Sąd, przeprowadzając kontrolę, powinien zbadać fakt posiadania legitymacji uczestników postępowania mediacyjnego do zawarcia ugody (Antolak-Szymański, Piaskowska, 2017, s. 211). Zaznaczyć jednak należy, że kontrola dopuszczalności ugody nie powinna polegać na merytorycznym rozpoznawaniu postępowania przez sąd (Góra-Błaszczykowska (red.), Legalis 2020).

Nie bez znaczenia jest kwestia, jak omawiane zastrzeżenie wpływa na możliwość zatwierdzenia ugody, która obejmuje swoją treścią zakres wykraczający poza ramy przedmiotowego roszczenia. Co do zasady ugoda mediacyjna nie powinna przekraczać granic postępowania, z którym jest związana. 
Odmiennie od mediacji, do której strony zostały skierowane przez sąd, $\mathrm{w}$ mediacjach umownych dopuszczalne jest zawieranie w ugodzie roszczeń, które nie są ujęte w pozwie. W sytuacji wykroczenia przez uczestników mediacji sądowej poza zakres objęty pozwem, winno się przyjąć, że sąd zatwierdzi ugodę wyłącznie $w$ takim zakresie, $w$ jakim odnosi się ona do zgłoszonego w postępowaniu roszczenia (Antolak-Szymański, Piaskowska, 2017, s. 224). Potwierdzeniem takiego twierdzenia jest fakt, że mediacja sądowa dąży do wypracowania wspólnej ugody, która zmierza do zakończenia sporu oraz umorzenia postępowania sądowego. Strony postępowania powinny tym samym działać w porozumieniu celem chociażby częściowego wyeliminowania dzielącego je sporu. Wspólne ustępstwa stron mogą zmierzać do modyfikacji zakresu żądań, które zostały sformułowanie w pozwie bądź też do zrealizowania ich $\mathrm{w}$ formie zadośćuczynienia. Jeżeli zatem zostanie przyjęte, że ugoda nie powinna wykraczać poza granice pozwu, to również możliwość czynienia przez strony wzajemnych ustępstw, które zmierzają do zażegania konfliktu, okazałaby się ograniczonym żądaniem pozwu i nie powinna być przeszkodą w podejmowaniu próby wypracowania ugody, nie powinna również przesądzać o granicach wzajemnych ustępstw, szczególnie jeżeli strony dobrowolnie zmierzały do zakończenia istniejącego pomiędzy nimi konfliktu (Samoiłło-Dąbrowska, 2019, s. 81).

W kontekście powyżej przeanalizowanej kwestii zwarcie ugody w przypadku przekroczenia granic pozwu jest dopuszczalne, o ile zmierza do faktycznego uchylenia sporu, który jest przedmiotem postępowania sądowego. To właśnie $\mathrm{w}$ takim zakresie uznaje się za dopuszczalne zatwierdzenie przez sąd ugody, która wykracza poza roszczenie ujęte w pozwie (Dąbrowski, 2013, s. 41).

Jednocześnie w praktyce w omawianej sytuacji strony zazwyczaj decydują się złożyć przed mediatorem dodatkowy wniosek o przeprowadzenie mediacji umownej, który obejmuje swym zakresem taką część porozumienia, która może zostać objęta mediacją sądową, oraz zawrzeć w tym zakresie ugodę, a następnie możliwość zatwierdzenia jej przed sądem. Zdarza się również, że dla stron wystarczające jest spisanie oddzielnego porozumienia, poza realizowaną mediacją, a także postępowaniem sądowym (Smoiłło-Dąbrowska, 2013, s. 41). 
Tym samym należy stwierdzić, że sąd może odmówić nadania klauzuli wykonalności ugodzie, która została zawarta przed mediatorem, albo też odmówić jej zatwierdzenia, w sytuacji gdy pojawią się przesłanki jednoznacznie określone w art. $183^{14} \S 3$ k.p.c. Trzy pierwsze wymienione przesłanki odpowiadają tym, które zostały wskazane w sytuacji niedopuszczalności zawarcia ugody sądowej lub cofnięcia pozwu, co zostało wymienione w art. 223 $\$ 2$ k.p.c. w zw. z art. $203 \$ 4$ k.p.c. (Zieliński, Flaga-Gieruszyńska (red.), 2020).

Badania zagadnienia niezgodności ugody mediacyjnej z prawem wobec zawarcia jej w celu obejścia prawa warto zacząć od analizy treści art. 58 Kodeksu cywilnego (dalej: k.c.), który odnosi się do bezprawności czynności prawnej. Wobec tego niedopuszczalna jest czynność prawna, jeśli jest ona sprzeczna z przepisami ustawy, które są bezwzględnie obowiązujące, tj. ugoda mediacyjna jest bezprawna, gdy jej postanowienia nie pozostawiają stronie swobody odmiennego uregulowania treści stosunku prawnego. $Z$ powyższymi przepisami mamy do czynienia m.in. na podstawie przepisów Kodeksu cywilnego, który odnosi się do prawa rzeczowego oraz prawa spadkowego bądź też prawa rodzinnego. Za sprzeczne z ustawą czynności trzeba uznać również takie, które mają cel niezgodny z ustawą. Tym samym przez ugodę, której treść dąży do obejścia prawa, można rozumieć taką ugodę, która jedynie pozornie jest zgodna z ustawą. Należy przez to rozumieć, że późniejsze konsekwencje takiej ugody naruszają zakazy czy też nakazy ujęte w ustawie. Obejściem ustawowej regulacji w przypadku ugody, która jest zawierana w sprawach gospodarczych, byłoby np. zawarcie jej pomiędzy osobą jako organem osoby prawnej oraz taką osobą jako drugą stroną. Powyższe działanie jest złamaniem ustawowego zakazu określonego w art. 108 k.c., czyli zakazu dokonywania czynności z samym sobą (https://lexplay.pl/artykul/Postepowanie-Sadowe/sadowa kontrola ugody zawartej w postepowaniu mediacyjnym 1).

Następną ustawową przesłankę stanowi sprzeczność ugody z zasadami współżycia społecznego. Wobec tego, że w obowiązujących przepisach nie ma jednoznacznej legalnej definicji, która odnosiłaby się do pojęcia zasad współżycia społecznego, to przesłanka ta powinna podlegać każdorazowo oddzielnej, indywidualnej ocenie w przedmiocie zawartych w ugodzie postanowień. Na przykład za sprzeczną z zasadami współżycia społecznego można by uznać taką ugodę, której postanowienia są krzywdzące dla strony, 
naruszają jej interesy oraz zmierzają do wykluczenia możliwości dochodzenia przez nią roszczenia. Wyżej wskazane kwestie pozostają aktualne, gdy $\mathrm{w}$ postępowaniu mediacyjnym mamy do czynienia $\mathrm{z}$ podmiotami o różnych pozycjach, w sytuacji rozwiązywania sporu przez profesjonalistów w obrocie gospodarczym lub podmioty działające przez profesjonalnych pełnomocników w zestawieniu z jednostką, która występowała w procesie samodzielnie czy też z podmiotem niebędącym w stanie przewidzieć następstw przeprowadzonego postępowania (Samoiłło-Dąbrowska, 2019, s. 81).

Ponadto wymaga wyjaśnienia, jak rozumieć kwestię, kiedy ugoda jest niezrozumiała, czyli jest niejasna, niejednoznaczna, i kiedy jej odczytanie powoduje trudności w rozumieniu właściwej i pożądanej treści oraz intencji stron postępowania (Zachorowska, 2020, s. 89).

Sprzeczność ujęta w treści ugody będzie występowała natomiast, gdy poszczególnie postanowienia będą się wzajemnie wykluczały, a interpretacja ugody nie będzie prowadzić do usunięcia rozbieżności, które będą uniemożliwiały jej wykonanie (Marciniak, Piasecki (red.), 2020). Co ciekawe, do najczęściej spotykanych błędów w tym zakresie prowadzi brak znajomości aktualnie obowiązujących przepisów przez uczestników mediacji czy też brak kwalifikacji oraz umiejętności praktycznych mediatorów. Dlatego decydując się na mediację, warto szczególną uwagę zwrócić na to, kto będzie ją prowadził. Bowiem wewnętrzne sprzeczności pojawiające się w treści ugody oraz jej nieczytelność często implikują konieczność wprowadzenia odpowiednich postanowień w ugodzie na podstawie obowiązujących przepisów. Powyższe umożliwia nadanie przez sąd ugodzie klauzuli wykonalności, co pozwala na ewentualne skierowanie sprawy na drogę postępowania egzekucyjnego. Przy samym sformułowaniu ugody bardzo pomocne jest wykształcenie czy wiedza prawnicza. Jednocześnie w zależności od kategorii sprawy, której dotyczy postępowanie mediacyjne, przy rozpatrywaniu przesłanek, które warunkują możliwość zatwierdzenia ugody zawartej przed mediatorem, sąd winien również zwrócić uwagę na konkretne wymogi, które wynikają z przepisów szczególnych (Samoiłło-Dąbrowska, 2019, s. 81).

Jako przykład sytuacji, w której pojawiają się dodatkowe kryteria kontroli czynności, można wskazać sprawy z zakresu prawa pracy i ubezpieczeń społecznych, tj. naruszenie słusznego interesu pracownika lub ubezpieczonego, 
o czym mówi art. 469 k.p.c. (Marszałkowska-Krześ (red.), 2020). Bowiem dopuszczalność zawierania ugód zarówno sądowych, jak i pozasądowych pomiędzy pracownikami a pracodawcą zawężają $\mathrm{w}$ istotny sposób przepisy określone w prawie pracy, np. art. 84 Kodeksu pracy. Zgodnie z wskazanym artykułem pracownik nie może zrzec się prawa do wynagrodzenia ani przenieść tego prawa na inną osobę. Zakaz ten ma charakter bezwzględny i dotyczy także zrzeczenia się prawa do wynagrodzenia za pracę w drodze wszelkich oświadczeń woli pracownika, w tym także w drodze ugody sądowej. Tym samym ugoda sądowa powinna być zgodna ze słusznym interesem pracownika, natomiast jej treść obligatoryjnie należy poddać analizie, biorąc pod uwagę przysługujące pracownikowi roszczenia (Wolińska-Uchman, 2012, s. 190).

Oczywiste jest to, że sąd może uznać, z punktu widzenia słusznego interesu pracownika czy ubezpieczonego, za czynności sprzeczne z prawem i zasadami współżycia społecznego bądź też zmierzające do obejścia prawa już samo zawarcie ugody w sprawie (art. $223 \$ 2$ w zw. z art. $203 \$ 4$ k.p.c.). Ponadto za czynności takie sąd uzna cofnięcie pozwu czy też zrzeczenie się lub ograniczenie roszczenia przez pracownika, o czym traktuje art. 203 $\$ 4$ k.p.c. (Góra-Błaszczykowska (red.), 2016). Można przyjąć, że ugoda, która została zawarta w zakresie dotyczącym stosunku pracy i roszczeń pracowników wobec pracodawcy, nie powinna być w żaden sposób krzywdząca względem pracownika (Marciniak (red.), 2020). W sytuacji zauważenia jakiejkolwiek z tych przesłanek sąd winien uznać ugodę za niedopuszczalną oraz poinformować o tym fakcie strony, a następnie przeprowadzić postępowanie oraz zakończyć sprawę w ramach stosownego rozstrzygnięcia. Jeśli stanowisko sądu nie dopuści treści ugody, to powinno zostać to ujęte $\mathrm{w}$ protokole. Jednocześnie uzasadnienie postanowienia sądu powinno znaleźć się w motywach orzeczenia, które rozstrzyga spór (Góra-Błaszczykowska (red.), 2020, art. 425-729).

Sąd posiada szerokie uprawnienia, w tym do kontroli ugody w zakresie, który wykracza poza postanowienia określone w art. $183^{14} \S 3$ k.p.c. Sąd poddaje kontroli treść ugody także w sytuacji, gdy strony nie zastosowały wymaganej formy dla czynności prawnej, o czym mówi art. 158 k.c. Jako przykład można wskazać sprawy o zniesienie współwłasności, działowe lub o podział 
majątku pomiędzy małżonkami, gdy przedmiot ugody stanowi nieruchomość. Zarówno w doktrynie, jak i judykaturze przyjmuje się powszechnie, że w sytuacji gdy przeniesienie własności nieruchomości następuje w ramach zawarcia ugody przed sądem, w ramach toczącego się postępowania, w postępowaniu pojednawczym lub przed sądem polubownym, ugoda zastępuje formę aktu notarialnego (Pietrzykowski (red.), 2020; Samoiłło-Dąbrowska, 2019, s. 81). Kwestie te nie dotyczą jednak ugody zawartej przed mediatorem na podstawie art. $183^{15} \$ 2$ k.p.c. W takim przypadku konieczne jest zachowanie formy aktu notarialnego (I CKN 753/99, Legalis; I ACa 404/16, Legalis; Góra-Błaszczykowska, 2020).

Warto jednak wskazać, że w analizowanej powyżej sytuacji istnieje także możliwość ujęcia przez sąd treści ugody mediacyjnej w ugodzie, która została zawarta przed sądem w toku postępowania zainicjowanego przez jedną ze stron. Powyższe rozwiązanie jest dopuszczalne zarówno w odniesieniu do mediacji, do której strony zostały skierowane przez sąd, jak i w mediacji umownej. W pierwszej sytuacji sąd zamiast zatwierdzić ugodę mediacyjną, wobec tego, że taka możliwość nie istnieje, może umieść w ugodzie sądowej rozwiązanie, które pozwoli stronom uniknąć kosztów, które będą związane z koniecznością sporządzenia ugody w formie aktu notarialnego. W przypadku gdy ugoda została ujęta w postępowaniu mediacyjnym na skutek umowy, to aby sąd mógł przenieść treść tej ugody do ugody sądowej, strony powinny przede wszystkim wszcząć odpowiednie postępowanie. W takiej sytuacji już na etapie pierwszego pisma strony powinny wnioskować o ujęcie treści ugody w orzeczeniu, które zostanie wydane przez sąd, wyrażając jednocześnie wolę ugodowego rozwiązania sporu (Samoiłło-Dąbrowska, 2019, s. 81).

\section{Przesłanki uzNania ugody za tytue EGZEKUCYJNY, A NASTĘPNIE TYTUŁ WYKONAWCZY}

Problematyczne w przedmiotowym zagadnieniu jest to, że Kodeks postępowania cywilnego nie zawiera definicji ugody mediacyjnej. W dostępnej literaturze można wyczytać, że przyjęto, iż powinna ona odpowiadać warunkom, które zostały określone w art. 917 k.c., zgodnie z którym: „przez ugodę strony czynią sobie wzajemne ustępstwa w zakresie istniejącego między nimi 
stosunku prawnego w tym celu, aby uchylić niepewność co do roszczeń wynikających $\mathrm{z}$ tego stosunku lub zapewnić ich wykonanie albo by uchylić spór istniejący lub mogący powstać”. Jak każda ugoda, jest ona czynnością prawną o charakterze obligacyjnym, „której przedmiotem będą wszelkie stosunku prawne, którymi strony mogą swobodnie rozporządzać” (Cebula, 2012, s. 51). Znawcy materii uznają, że ugoda zawarta w mediacji ze skierowania sądu jest połączeniem elementów „umowy cywilnoprawnej, zmierzającej do wywołania skutków materialnoprawnych w zakresie istniejącego między stronami stosunku prawnego” (Dąbrowski, 2013, s. 46) oraz „czynności procesowej zmierzającej do umorzenia postępowania” (tamże). Na podstawie stanowiska Sądu Najwyższego (III PZP 43/69, OSNCP 1970, nr 3, poz. 40) do oceny umowy cywilnoprawnej powinno się stosować przepisy prawa cywilnego materialnego, natomiast do oceny jej skutków procesowych - prawo procesowe (Dąbrowski, 2013, s. 46).

Co więcej, ustawodawca nie przewidział regulacji prawnej formy zawarcia ugody mediacyjnej. Wobec tego może mieć ona formę dowolną, również ustną, chyba że dotyczy sytuacji, w której wymagana jest forma szczególna (Dąbrowski, 2013, s. 46). Jeśli natomiast do mediacji doszło ze skierowania sądu, zawarta w jej wyniku ugoda wymaga formy co najmniej pisemnej (tamże).

Warto mieć na względzie, że sporządzenie ugody mediacyjnej nie jest obowiązkiem mediatora, ponieważ jego pomoc może polegać wyłącznie na zakreśleniu szkicu ugody.

Ugoda mediacyjna może być sformułowana przez same strony czy też ich pełnomocników.

W ramach zatwierdzenia ugody sąd poddaje badaniu następujące kwestie:

a) czy zapisy ugody są jasne i zrozumiałe dla czytającego;

b) czy ugoda nie zawiera sprzeczności, tj. czy jej zapisy wzajemnie się nie wykluczają lub nie są wobec siebie sprzeczne;

c) czy ugoda mediacyjna nie służy obejściu przepisów prawa;

d) czy ugoda mediacyjna nie jest niezgodna z zasadami współżycia społecznego. Jednocześnie ugoda powinna być napisana zwięźle.

Powinna zawierać:

a) oznaczenie stron, które ją zawierają; 
b) informację, czy strony zawierają ją w zakresie postępowania sądowego, w którym zostały skierowane do mediacji, czy w ramach mediacji umownej;

c) odniesienie do sygnatury, w której sąd skierował sprawę do mediacji;

d) sposób, w jaki strony się porozumiały; sędzia, który będzie zatwierdzał ugodę, nie może mieć wątpliwości co do jej treści oraz tego, w jaki sposób strony się porozumiały;

e) zapisy dotyczące tego, co się stanie, jeśli strony (bądź jedna z nich) nie wywiążą się z warunków ugody;

f) zapis dotyczący podziału i wysokości kosztów mediacji oraz informację, kto je ponosi i w jakiej części;

g) informację dotyczącą kosztów zastępstwa procesowego - czy strony znoszą te koszty, czy może zostają one opłacone przez jedną ze stron;

h) zapisy dotyczące wnoszenia zmian do ugody wyłącznie w formie pisemnej pod rygorem nieważności;

j) informację, w ilu egzemplarzach została podpisana ugoda i dla kogo są one przeznaczone.

Ugoda może również zawierać załączniki oraz preambułę (jeśli konieczne jest to do dobrego zrozumienia jej zapisów) (https://starogard-gd.sr.gov. pl/fileCheck.php?file=poradnik-mediacje-w-sprawach-gospodarczychskuteczne-narzedzia-1608116019.pdf).

Natomiast w art. $777 \$ 1$ k.p.c. wymienia się większość tytułów egzekucyjnych, które - po zaopatrzeniu ich w klauzulę wykonalności - stają się tytułami wykonawczymi. Jak bowiem stanowi art. 776 k.p.c., „podstawą egzekucji jest tytuł wykonawczy, jeżeli ustawa nie stanowi inaczej. Tytułem wykonawczym jest tytuł egzekucyjny zaopatrzony w klauzulę wykonalności”. Przez tytuł egzekucyjny można rozumieć dokument urzędowy, stwierdzający istnienie i zakres nadającego się do egzekucji roszczenia wierzyciela i jednocześnie istnienie oraz zakres obowiązku prawnego dłużnika (Ereciński, 2006, s. 433). Zakłada się, że tytuł egzekucyjny jest oryginałem odpisu protokołu sądowego, który zawiera treść ugody podpisanej przez strony z jednoczesnym warunkiem, że po podpisaniu jej przez strony sąd wydał postanowienie o umorzeniu postępowania. Jednak dopiero po 
stwierdzeniu prawomocności ugody może zostać nadana jej klauzula wykonalności. Dopiero od tego momentu można uważać, że ugoda taka jest zgodna z prawem, zasadami współżycia społecznego oraz rażąco nie narusza usprawiedliwionego interesu osób uprawnionych. Warto jednak mieć na uwadze, że w postępowaniu pojednawczym sąd nie może wydać postanowienia o umorzeniu postępowania.

Ważna będzie również taka ugoda, która zostanie zawarta poza granicami powództwa. Z kolei nie może stanowić tytułu egzekucyjnego ugoda, której treść obejmuje odesłanie do dalszych umów, które mają wejść w skład ugody sądowej. Wobec powyższego ugody, które są zawarte przed sądem powszechnym w sprawach cywilnych, są tytułami egzekucyjnymi, w przypadku gdy zostaną ujęte w protokole sądowym i zawierają obowiązek świadczenia. Za tytuł egzekucyjny można uznać także oryginał protokołu sądowego (https://www.podatki.biz/artykuly/ugoda-jako-tytul-wykonawczy-wpostepowaniu-egzekucyjnym_33_21537.htm).

Co istotne, ugoda, analogicznie jak w przypadku innych tytułów egzekucyjnych, winna określać obowiązek dłużnika, który nadaje się do wykonania w ramach przymusu. Jednocześnie jeżeli ugoda wymienia kilka obowiązków, to może zostać tytułem wykonawczym tylko w odniesieniu do tych, które są możliwe do wykonania. Nie jest dopuszczalne uznanie wykonalności ugody, w której strony uzależniły ważność jej postanowień od warunku, czyli jeżeli uznano, że wykonanie świadczenia uzależnione jest od zrealizowania warunku zawieszającego lub rozwiązującego. Powyższa ugoda może stać się tytułem egzekucyjnym dopiero po spełnieniu warunku. Nie jest dopuszczalne natomiast przyjmowanie do protokołu ugody, która zawiera warunek i od której zależy ważność ugody. Podobnie należy traktować ugodę, na podstawie której ustalono dla jednej lub obu stron ugody możliwość odstąpienia od niej czy też jej rozwiązania. Warto pamiętać, że taka ugoda nie może być tytułem egzekucyjnym.

Podsumowując, ugoda, która jest zawarta przed mediatorem, po jej zatwierdzeniu przez sąd ma moc prawną ugody, która jest zawarta przed sądem. Ugoda taka nie stanowi tytułu egzekucyjnego, lecz od razu przeobraża się w tytuł wykonawczy, gdy zostanie zatwierdzona przez nadanie klauzuli wykonalności. Na marginesie warto dodać, że na kwestię monitoringu 
wykonania zawartych ugód mediacyjnych zwrócono uwagę w literaturze przedmiotu, wskazując na dwa ich typy. Pierwszym z nich są ugody bezpośrednio wykonalne, w których wykonanie warunków jest zarówno „wymierne i natychmiastowe” (Moore, 2003, s. 352), jak i „niebezpośrednio wykonalne" (tamże), które ze względu na swoje cechy wymagają realizacji przez dłuższy czas. Jak pokazuje teoria oraz praktyka, porozumienia, które nie są bezpośrednio wykonalne, są podłożem późniejszych konfliktów „Związanych $\mathrm{z}$ odrębną interpretacją uzgodnionych w przeszłości warunków” (tamże, s. 353).

\section{ODMOWA ZATWIERDZENIA UGODY LUB NADANIA KLAUZULI WYKONALNOŚCI ORAZ MOŻLIWOŚĆ PÓŹNIEJSZEGO ZASKARŻENIA POSTANOWIEŃ W TYM ZAKRESIE}

W ramach przeprowadzonej analizy można przyjąć, że sąd odmawia nadania klauzuli wykonalności albo zatwierdzenia w całości lub w części ugody mediacyjnej, gdy w jej treści pojawiają się okoliczności wymienione w $\$ 3$ art. $183^{14}$ k.p.c. Jednocześnie każdorazowo o odmowie zatwierdzenia ugody, która została zawarta przed mediatorem, a także o przyczynach takiej odmowy, sąd informuje mediatora. Obowiązek ten wynika z $\$ 172$ Rozporządzenia Ministra Sprawiedliwości - Regulaminu urzędowania sądów powszechnych (Dz.U. z 2019 r. poz. 1141 ze zm.). Według przepisu art. $183^{14}$ k.p.c.:

$\$ 1$. Jeżeli zawarto ugodę przed mediatorem, sąd, o którym mowa $\mathrm{w}$ art. $183^{13}$, na wniosek strony przeprowadza niezwłocznie postępowanie co do zatwierdzenia ugody zawartej przed mediatorem.

$\$ 2$. Jeżeli ugoda podlega wykonaniu w drodze egzekucji, sąd zatwierdza ją przez nadanie jej klauzuli wykonalności; w przeciwnym przypadku sąd zatwierdza ugodę postanowieniem.

$\$ 3$. Sąd odmawia nadania klauzuli wykonalności albo zatwierdzenia ugody zawartej przed mediatorem, w całości lub części, jeżeli ugoda jest sprzeczna z prawem lub zasadami współżycia społecznego albo zmierza do obejścia prawa, a także gdy jest niezrozumiała lub zawiera sprzeczności. 
Tym samym zgodnie z brzmieniem art. $183^{14} \S 2$ k.p.c. oraz art. 766 k.p.c. decyzję w przedmiocie zatwierdzenia ugody sąd wydaje na posiedzeniu niejawnym. Zgodnie natomiast $\mathrm{z}$ art. $148 \$ 2$ k.p.c. w każdej sytuacji w przypadku zaistnienia takiej potrzeby sąd może skierować sprawę na posiedzenie jawne oraz wyznaczyć rozprawę. A zatem przeprowadzenie rozprawy może prowadzić niejednokrotnie do wyjaśnienia wątpliwości co do przesłanek odmowy zatwierdzenia ugody albo ułatwić stronom wprowadzenie koniecznych zmian do treści porozumienia, tak aby doprowadzić do zrealizowania ugody w formie mediacyjnej czy też rozstrzygnięcia sądu (Góra-Błaszczykowska, 2020).

Zgodnie $\mathrm{z}$ art. $394^{\text {la }} \$ 1$ pkt 11 k.p.c. na postanowienie sądu w przedmiocie zatwierdzenia ugody przysługuje zażalenie do innego składu sądu I instancji. Sąd podejmuje decyzję w zakresie zatwierdzenia ugody na posiedzeniu niejawnym. Tak mówi art. $183^{14} \S 2$ in fine k.p.c., a także art. $148 \$ 3$ k.p.c. w aktualnym brzmieniu. $Z$ uwagi na powyższe postanowienie sądu w tym zakresie jest doręczane $\mathrm{z}$ urzędu. Uzasadnienie jest sporządzane $\mathrm{z}$ urzędu wyłącznie wtedy, gdy sąd wydał postanowienie o zatwierdzeniu ugody, która została zawarta przed mediatorem, o czym mówi art. $357 \$ 2$ k.p.c. Zgodnie natomiast $\mathrm{z}$ art. $357 \S 2^{1}$ k.p.c. postanowienie wydane na posiedzeniu niejawnym sąd uzasadnia tylko wtedy, gdy podlega ono zaskarżeniu, i wyłącznie na żądanie strony zgłoszone $\mathrm{w}$ terminie tygodnia od dnia doręczenia postanowienia. Postanowienie z uzasadnieniem doręcza się tylko tej stronie, która zażądała sporządzenia uzasadnienia i doręczenia postanowienia $\mathrm{z}$ uzasadnieniem. Odbierając doręczane jej postanowienie, strona, która występuje w sprawie bez adwokata, radcy prawnego, rzecznika patentowego lub radcy Prokuratorii Generalnej Rzeczypospolitej Polskiej, zostanie pouczona o dopuszczalności, terminie i sposobie wniesienia środka zaskarżenia. Jeśli zatwierdzenie ugody zawartej przed mediatorem następuje w wyniku nadania jej klauzuli wykonalności, wówczas zażalenie na postanowienie przysługuje zgodnie $\mathrm{z}$ art. $795 \$ 1$ k.p.c. (Góra-Błaszczykowska, Legalis 2020).

Jednocześnie zaskarżeniu zażaleniem podlega postanowienie sądu, zarówno pozytywne, jak i negatywne, $\mathrm{w}$ zakresie zatwierdzenia ugody, która została zawarta przed mediatorem. Co więcej, może pojawić się problem z zaskarżeniem ugody, która może podlegać wykonaniu w drodze egzekucji. 
Zgodnie $\mathrm{z}$ art. $183^{14}$ k.p.c. tego rodzaju ugodę co do zasady zatwierdza się w ramach nadania jej klauzuli wykonalności. Na podstawie art. $795 \$ 1$ k.p.c. na postanowienie sądu w przedmiocie nadania klauzuli wykonalności przysługuje zażalenie (Flaga-Gieruszyńska, Zieliński, 2020).

Trzeba wykluczyć przede wszystkim jednak konkurencyjność zażaleń czy zażalenia na zatwierdzenie ugody zawartej przed mediatorem zgodnie $\mathrm{z}$ art. $394^{1 \mathrm{a}} \$ 1$ pkt 11 k.p.c. i zażalenia na klauzulę wykonalności. Kluczowa kwestia sprowadza się do „zatwierdzenia ugody”, a tym samym do sposobu jej zatwierdzenia w ramach nadania klauzuli wykonalności. W takiej sytuacji przysługuje zatem stronom zażalenie zgodnie $\mathrm{z}$ art. $394^{\text {la }} \$ 1$ pkt 11 k.p.c., a nie na podstawie art. $795 \$ 1$ k.p.c. W takim wypadku należy uznać, że jeśli nie dojdzie do nadania ugodzie klauzuli wykonalności, to zażalenie na jej nadanie jest niedopuszczalne (Zembrzuski, 2013, s. 431).

Ugoda zawarta przed mediatorem, o której zatwierdzenie przez sąd nie wystąpiła żadna ze stron, oraz ugoda, której zatwierdzenia sąd odmówił, może mieć wyłącznie skutek ugody pozasądowej. Wobec tego taka ugoda może być wyłącznie uznana za umowę, której ważność oraz skuteczność podlegają ocenie w świetle prawa materialnego (Marciniak (red.), 2019). Jeśli natomiast przedmiotowa ugoda może podlegać wykonaniu w drodze egzekucji, sąd zatwierdza ją poprzez nadanie klauzuli wykonalności. W odmiennej sytuacji sąd wydaje postanowienie o zatwierdzeniu ugody. Ugoda, która zatwierdzona jest przez sąd, zgodnie z art. $183^{15}$ k.p.c. zyskuje moc ugody sądowej. Natomiast ugoda, która została zawarta przed mediatorem oraz zatwierdzona przez nadanie jej klauzuli wykonalności, staje się tytułem wykonawczym (Flaga-Gieruszyńska, Zieliński, Legalis 2020; Samoiłło-Dąbrowska, 2019, s. 81).

\section{Podsumowanie}

Niniejszy artykuł wyłącznie częściowo nakreśla problematykę związaną z walorami ugody mediacyjnej i konsekwencjami związanymi z ewentualnym niewywiązaniem się z ugody oraz możliwości przeprowadzenia postępowania egzekucyjnego na podstawie ugody, która zostanie zaopatrzona w klauzulę wykonalności. Poza kwestiami w nim opisanymi należy wskazać, że 
przez ugodę, która została podjęta przed mediatorem, trzeba rozumieć taką ugodę, która została zawarta w postępowaniu pojednawczym, o czym mówią art. 184-186 k.p.c., a także w postępowaniu rozpoznawczym, w trybie procesowym oraz nieprocesowym, a także w postępowaniu przed mediatorem, po zatwierdzeniu jej przez sąd, czy też w postępowaniu karnym, w ramach którego wytoczono powództwo adhezyjne, oraz $\mathrm{w}$ postępowaniu $\mathrm{z}$ oskarżenia prywatnego. Warto zwrócić uwagę również na to, że tytułami egzekucyjnymi mogą stać się także ugody, które zostały zawarte przed sądami zagranicznymi, o czym mówi art. 1152 k.p.c., oraz przed sądami szczególnymi.

Jednocześnie, co ważne, w ramach niniejszego artykułu należy przyjąć, że potwierdziła się hipoteza badawcza, że w przypadku niewywiązania się z postanowień ugody, w ramach której strony zobowiązały się do zrealizowania określonego świadczenia, skutecznym rozwiązaniem jest złożenie wniosku o nadanie klauzuli wykonalności ugodzie mediacyjnej, uzyskanie tytułu wykonawczego i skierowanie sprawy na drogę postępowania egzekucyjnego. W niniejszym artykule jednak podkreślono, że w przypadku niewywiązania się z ugody wyłącznie właściwa forma postanowień w niej ujętych oraz ziszczenie się określonych przesłanek umożliwiają nadanie jej klauzuli wykonalności, a następnie przeprowadzenie postępowania egzekucyjnego.

Warto także podkreślić $\mathrm{w}$ podsumowaniu, że zgodnie $\mathrm{z}$ art. 71 ust. 1 Ustawy o kosztach sądowych w sprawach cywilnych z dnia 16 kwietnia $2020 \mathrm{r}$. (Dz.U. z 2020 r. poz. 755) opłatę stałą w kwocie 50 zł pobiera sąd od wniosku o nadanie klauzuli wykonalności tytułowi egzekucyjnemu innemu niż orzeczenie sądu, ugoda sądowa, nakaz zapłaty albo ugoda zawarta przed mediatorem w wyniku prowadzenia mediacji na podstawie postanowienia sądu kierującego strony do mediacji. Warto również zaznaczyć, że zgodnie z treścią wskazanego wyżej przepisu $\mathrm{z}$ obowiązku tego zwolniona została ugoda zawarta przed mediatorem $\mathrm{w}$ wyniku prowadzenia mediacji na podstawie postanowienia sądu kierującego strony do mediacji. Tym samym opłacie, zgodnie z brzmieniem przytoczonego przepisu, powinien podlegać jedynie wniosek o zatwierdzenie ugody mediacyjnej poprzez nadanie jej klauzuli wykonalności, ale wyłącznie w przypadku ugód zawartych w ramach mediacji umownej, ponieważ postępowanie pozasądowe nie zostało objęte ramami art. 71 pkt 1 ustawy o kosztach sądowych w sprawach cywilnych (Zieliński, 
Legalis 2019). Natomiast zgodnie z art. 95 ust. 1 pkt 9 ww. ustawy nie pobiera się opłat od wniosku o zatwierdzenie ugody zawartej przed mediatorem w wyniku prowadzenia mediacji na podstawie umowy o mediację.

Wobec tego obecnie wniosek o nadanie klauzuli wykonalności ugodzie mediacyjnej zawartej przed mediatorem w wyniku prowadzenia mediacji na podstawie postanowienia sądu kierującego strony do mediacji oraz zatwierdzenie ugody zawartej przed mediatorem nie podlega opłacie.

Co równie istotne, skutki niewykonania przez dłużnika obowiązku, który wynikał z ugody sądowej, w przypadku braku odmiennych postanowień umownych określone są w art. 471 i następnych Kodeksu cywilnego. Wobec powyższego ugoda sądowa, która przewiduje obowiązek zapłaty świadczenia pieniężnego z pominięciem stwierdzenia o obowiązku zapłaty odsetek, nie jest tytułem egzekucyjnym w zakresie odsetek za opóźnienie na wypadek braku realizacji świadczenia pieniężnego w terminie ustalonym w ugodzie. W takiej sytuacji konieczne jest uzyskanie tytułu egzekucyjnego, który obejmuje także taki obowiązek.

Reasumując, dążenie do zawarcia ugody w ramach procesu mediacyjnego ma wiele walorów, jednak dla skutecznego ewentualnego dochodzenia swoich roszczeń na drodze egzekucyjnej istotne jest prawidłowe jej sformułowanie, w taki sposób, aby możliwe było nadanie ugodzie klauzuli wykonalności. Jednocześnie warto zauważyć, że przeprowadzone rozważania prowadzą do stwierdzenia, że art. $183^{14}$ k.p.c. nie reguluje w sposób wyczerpujący zagadnienia dotyczącego nadania klauzuli wykonalności ugodzie zawartej przed mediatorem. Brakuje bowiem w $\$ 2$ art. $183^{14}$ k.p.c. doprecyzowania tego, co należy rozumieć przez moment, kiedy ugoda podlega nadaniu jej klauzuli wykonalności. Warto uznać, że jeśli zgodnie z postanowieniami ugody podlega ona np. natychmiastowemu wykonaniu w drodze egzekucji albo jeśli wierzyciel zgodnie $\mathrm{z}$ art. $786 \$ 1$ k.p.c. wykaże ziszczenie się zdarzenia, od którego uzależniono wykonanie ugody, to sąd zatwierdza ją przez nadanie klauzuli wykonalności, w innym natomiast przypadku sąd zatwierdza ugodę $\mathrm{w}$ ramach postanowienia.

Ponadto warto również zwrócić uwagę na to, że na podstawie art. 795 $\$ 1$ k.p.c. na postanowienie sądu w przedmiocie nadania klauzuli wykonalności przysługuje zażalenie do sądu okręgowego. Natomiast zgodnie 
$\mathrm{z}$ art $394^{1 \mathrm{a}} \S 1$ pkt 11 k.p.c. zażalenie na postanowienie w przedmiocie zatwierdzenia ugody zawartej przed mediatorem należy złożyć do innego składu sądu I instancji. Należy podkreślić, że mediator nie jest organem procesowym, lecz „jedynie bezstronnym i neutralnym uczestnikiem postępowania mediacyjnego" (Sławicki, 2014, s. 136). Zawarta przed nim ugoda ma wyłącznie charakter dokumentu prywatnego i dopiero po zatwierdzeniu jej przez sąd ma „moc prawną ugody zawartej przed sądem” i wobec tego sama nie tworzy żadnych skutków postępowania (tamże, s. 137). Podsumowując, tylko skuteczne i rzetelne sformułowanie umowy czyni ugodę mediacyjną - oraz każdą inną ugodę - tytułem egzekucyjnym, który po złożeniu stosownego wniosku może zostać zaopatrzony w klauzulę wykonalności i stać się tytułem wykonawczym.

\section{Bibliografia}

Antolak-Szymański, K., Piaskowska, O.M. (2017). Mediacja w postępowaniu cywilnym. Komentarz, Warszawa: Wolters Kluwer, s. 211. ISBN 9788381070089.

Cebula, R. (2012). Zakres przedmiotowy ugody mediacyjnej. W: W. Broński, P. Stanisz, Mediacje i negocjacje prawnicze, Lublin: Katolicki Uniwersytet Lubelski, s. 51.

Dąbrowski, M. (2013). Charakter prawny ugody mediacyjnej zawartej po wszczęciu postępowania cywilnego, „ADR. Arbitraż i Mediacja”, nr 1, s. 41.

Ereciński, T. (2006). W: T. Ereciński (red.), Kodeks postępowania cywilnego. Komentarz, t. I, Warszawa: LexisNexis, s. 433.

Flaga-Gieruszyńska, K., Zieliński, A. (2020). Kodeks postępowania cywilnego. Komentarz, wyd. 10, Warszawa: Legalis.

Flaga-Gieruszyńska, K., Zieliński, A. (2020). Zażalenie w postępowaniu cywilnym. Komentarz praktyczny z orzecznictwem. Wzory pism procesowych, Warszawa: Wydawnictwo C.H. Beck.

Gmurzyńska, E. (2007). Mediacja $w$ sprawach cywilnych $w$ amerykańskim systemie prawnym - zastosowanie w Europie i w Polsce, Warszawa: Wydawnictwo C.H. Beck, s. 360 .

Góra-Błaszczykowska, A. (red.) (2016). Kodeks postępowania cywilnego. Tom I. Komentarz. Art. 1-729, komentarz do art. 469, Nb 1, Warszawa: Wydawnictwo C.H. Beck. 
Góra-Błaszczykowska, A. (red.) (2020). Kodeks postępowania cywilnego. Tom I A. Komentarz. Art. 1-424 ${ }^{12}$, Warszawa: Legalis.

Góra-Błaszczykowska, A. (red.) (2020). Kodeks postępowania cywilnego. Tom I B. Komentarz. Art. 425-729, Warszawa: Wydawnictwo C.H. Beck.

Lichoń, K.A. (2020). W: Zakończenie postępowania mediacyjnego. Ugoda mediacyjna, Ochrona konsumenta w postępowaniu mediacyjnym i arbitrażowym, Warszawa: Wydawnictwo C.H. Beck, Legalis 2021.

Marciniak, A. (red.) (2019). Kodeks postępowania cywilnego. Tom I. Komentarz. Art. 1-205, Warszawa: Wydawnictwo C.H. Beck.

Marciniak, A. (red.) (2020). Kodeks postępowania cywilnego. Tom III. Komentarz do art. 425-729, Warszawa: Wydawnictwo C.H. Beck.

Marciniak, A., Piasecki, K. (red.) (2016). Kodeks postępowania cywilnego. T. I. Komentarz. Art. 1-366, Warszawa: Wydawnictwo C.H. Beck, Legalis 2020, ed. 7, komentarz do art. $183^{14}, \mathrm{Nb} 6$.

Marszałkowska-Krześ, E. (red.) (2020). Kodeks postępowania cywilnego. Komentarz, ed. 28, komentarz do art. 469, Nb 7, Legalis.

Moore, Ch.W. (2003). Mediacje - praktyczne strategie rozwiazzywania konfliktów, Warszawa: Wolters Kluwer, s. 352.

Mucha, J. (2020). Ugoda zawarta przed mediatorem a forma szczególna czynności prawnych, „ADR. Arbitraż i Mediacja”, nr 4, s. 49.

Pietrzykowski, K. (red.) (2020). Kodeks cywilny. T. I. Komentarz. Art. 1-44910, Wyd. 10, Warszawa: Wydawnictwo C.H. Beck.

Samoiłło-Dąbrowska, E. (2019). Procedura zatwierdzenia ugody zawartej przed mediatorem - praktyczne problemy, „ADR. Arbitraż i Mediacja”, nr 2, s. 81.

Sławicki, P. (2014). Charakter prawny ugody zawartej przed mediatorem w świetle nowelizacji K.P.C. $z$ dnia 16 września 2011 roku, „Studia Prawnicze KUL”, nr 4(60), s. 136.

Strumiłło, T. (2010). Skierowanie stron do mediacji przez sąd, „ADR. Arbitraż i Mediacja”, nr 3(11), s. 111.

Twardowska, E. (2020). Ugoda mediacyjna, Warszawa: Wydawnictwo ABC, Lex 2020.

Wolińska-Uchman (2012). A. Klauzula stusznego interesu pracownika jako przesłanka dopuszczalności zawarcia ugody, „Monitor Prawa Pracy”, nr 4, s. 190.

Zachorowska, J. (2020). Glosa do postanowienia Sadu Okregowego w Warszawie z 15 maja 2018 r., III C1381/14, „ADR. Arbitraż i Mediacja”, nr 3, s. 89. 
Zembrzuski, T. (2013). Zatwierdzenie ugody zawartej przed mediatorem (art. 394 $\$ 1$ pkt 101 k.p.c.). W: J. Gudowski (red.), System Prawa Procesowego Cywilnego, t. III, cz. 1, s. 431.

Zieliński, A. (2015), Koszty sądowe w sprawach cywilnych. Komentarz, ed. 9, komentarz do art. 71, Nb 1, Warszawa: C.H. Beck, Legalis 2019.

Zieliński, A., Flaga-Gieruszyńska, K. (red.) (2017). Kodeks postępowania cywilnego. Komentarz, ed. 9, komentarz do art. $183^{14}$, Nb 1, Warszawa: C.H. Beck, Legalis 2019.

\section{Akty prawne i orzecznictwo}

Postanowienie SA w Szczecinie z 17 września 2018 r., I AGz 87/18, Legalis.

Postanowienie SN z 8 stycznia 2002 r., I CKN 753/99, Legalis.

Uchwała SN z 20 grudnia 1969, III PZP 43/69, OSNCP 1970 nr 3, poz. 40.

Ustawa $\mathrm{z}$ dnia 17 listopada $1964 \mathrm{r}$. Kodeks postępowania cywilnego $\mathrm{z}$ dnia 7 sierpnia 2020 r. (Dz. U. z 2020 r. poz. 1575, ze zm.).

Ustawa $\mathrm{z}$ dnia 28 lipca 2005 r. o kosztach sądowych w sprawach cywilnych $\mathrm{z}$ dnia 16 kwietnia 2020 r. (Dz.U. z 2020 r. poz. 755 ze zm.).

Rozporządzenia Ministra Sprawiedliwości - Regulaminu urzędowania sądów powszechnych z dnia 18 czerwca 2019 r. (Dz.U. z 2019 r. poz. 1141 ze zm.).

Wyrok SA w Katowicach z 23 września 2016 r., I ACa 404/16, Legalis.

\section{Źródła internetowe}

https://lexplay.pl/artykul/Postepowanie-sadowe/sadowa kontrola ugody zawartej w postepowaniu mediacyjnym1 (dostęp: 6.01.2021).

https://www.podatki.biz/artykuly/ugoda-jako-tytul-wykonawczy-w-postepowaniuegzekucyjnym_33_21537.htm (dostęp: 6.01.2021).

http://www.starogard-gd.sr.gov.pl/wp-content/uploads/2019/01/Poradnik_Mediacjew-sprawach-gospodarczych-skuteczne-narzędzia.pdf (dostęp: 6.01.2021). 
